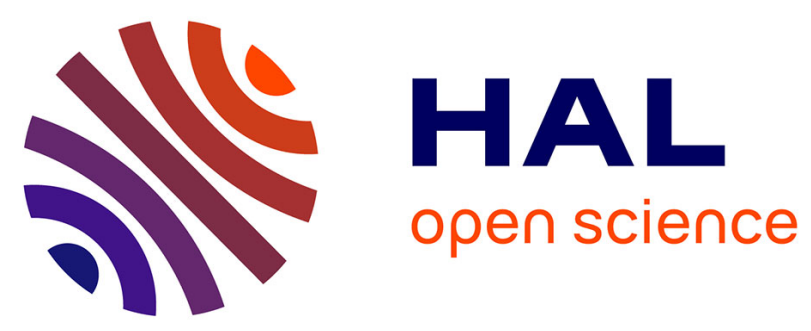

\title{
Cardiac effects of long-term active immunization with the second extracellular loop of human 31 - and/or ß3-adrenoceptors in Lewis rats
}

E Montaudon, Laurence Dubreil, Valerie Lalanne, M. Vermot Des Roches, Gilles Toumaniantz, Marion Fusellier, Jean-Claude Desfontis, Lionel Martignat, Mohamed Yassine Mallem

\section{To cite this version:}

E Montaudon, Laurence Dubreil, Valerie Lalanne, M. Vermot Des Roches, Gilles Toumaniantz, et al. Cardiac effects of long-term active immunization with the second extracellular loop of human 31 - and/or 33 -adrenoceptors in Lewis rats. Pharmacological Research, 2015, 100, pp.210-219. 10.1016/j.phrs.2015.08.006 . hal-01208120

\section{HAL Id: hal-01208120 \\ https://hal.science/hal-01208120}

Submitted on 27 May 2020

HAL is a multi-disciplinary open access archive for the deposit and dissemination of scientific research documents, whether they are published or not. The documents may come from teaching and research institutions in France or abroad, or from public or private research centers.
L'archive ouverte pluridisciplinaire HAL, est destinée au dépôt et à la diffusion de documents scientifiques de niveau recherche, publiés ou non, émanant des établissements d'enseignement et de recherche français ou étrangers, des laboratoires publics ou privés. 


\section{Cardiac effects of long-term active immunization with the second extracellular loop of human $\beta 1$ - and/or $\beta 3$-adrenoceptors in Lewis rats}

ARTICLE in PHARMACOLOGICAL RESEARCH · AUGUST 2015

Impact Factor: 4.41 · DOI: 10.1016/j.phrs.2015.08.006 · Source: PubMed

9 AUTHORS, INCLUDING:

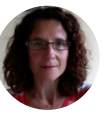

Valerie Lalanne

École Nationale Vétérinaire, Agroalimentair. .

7 PUBLICATIONS 81 CITATIONS

SEE PROFILE

\section{Desfontis Jean-Claude}

École Nationale Vétérinaire, Agroalimentair...

50 PUBLICATIONS 218 CITATIONS

SEE PROFILE

\section{Marion Fusellier}

École Nationale Vétérinaire, Agroalimentair...

20 PUBLICATIONS 68 CITATIONS

SEE PROFILE 


\title{
Cardiac effects of long-term active immunization with the second extracellular loop of human $\beta_{1}$ - and/or $\beta_{3}$-adrenoceptors in Lewis rats
}

\author{
E. Montaudon ${ }^{\mathrm{a}}$, L. Dubreil ${ }^{\mathrm{b}}$, V. Lalanne ${ }^{\mathrm{a}}$, M. Vermot Des Roches ${ }^{\mathrm{a}}$, G. Toumaniantz ${ }^{\mathrm{c}}$, \\ M. Fusellier ${ }^{\mathrm{d}}$, J.-C. Desfontis ${ }^{\mathrm{a}}$, L. Martignat ${ }^{\mathrm{e}}$, M.Y. Mallem ${ }^{\mathrm{a}, *}$ \\ a LUNAM University, Oniris, UPSP 5304 of Animal Pathophysiology and Functional Pharmacology, Atlanpôle La Chantrerie, BP 40706,44307 Nantes, France \\ ${ }^{\mathrm{b}}$ LUNAM University, Oniris, INRA UMR U703, PanTHER, Atlanpôle La Chantrerie, BP 40706, 44307 Nantes, France \\ ${ }^{c}$ LUNAM University, INSERM, UMR 1087/CNRS 6291, Institut du Thorax, Nantes F44007 France \\ ${ }^{\mathrm{d}}$ LUNAM University, Oniris, INSERM UMRS 791, LIOAD, Atlanpôle La Chantrerie, BP 40706, 44307 Nantes, France \\ e LUNAM University, Oniris, UPSP SSBR, Atlanpôle La Chantrerie, BP 40706, 44307 Nantes, France
}

\section{A R T I C L E I N F O}

\section{Article history:}

Received 6 March 2015

Received in revised form 28 June 2015

Accepted 7 August 2015

Available online 11 August 2015

\section{Keywords:}

Auto-antibodies

$\beta$-Adrenoceptor

Cardiac contractility

Dilated cardiomyopathy

Rats

\begin{abstract}
A B S T R A C T
$\beta_{1}$ - and $\beta_{3}$-adrenoceptor (AR) auto-antibodies were detected in patients with dilated cardiomyopathy. Many studies have shown that $\beta_{1}$-AR auto-antibodies with partial agonist-like effect play an important role in the pathogenesis of this disease. Moreover, a recent study carried out in our laboratory has shown that $\beta_{3}$-AR antibodies ( $\left.\beta_{3}-\mathrm{ABs}\right)$, produced in rats, were able to reduce cardiomyocyte contractility via $\beta_{3}$-AR activation. The aims of this study were (1) to investigate, in isolated cardiomyocytes from rabbit, the role of $G_{i}$ proteins in the $\beta_{3}-A B s$-induced cardiac negative inotropy, (2) to determine whether $\beta_{3}-A B s$ may exhibit $\beta_{3}$-AR antagonistic property which is characteristic of partial agonists, and (3) to determine whether long-term active immunization producing both $\beta_{1}$-ABs and/or $\beta_{3}$-ABs leads to the development of cardiac dysfunction in Lewis rats.

Lewis rats were immunized for 6 months with peptidic sequences corresponding to the second extracellular loop of human $\beta_{3}-\mathrm{AR}$ and/or $\beta_{1}$-AR. Agonistic effect of $\beta_{3}-\mathrm{ABs}$ was evaluated on electrically field-stimulated isolated cardiomyocytes from adult rabbit by measuring the cell shortening. Echocardiography and ex vivo isolated perfused heart studies were conducted on immunized rats. Finally, $\beta$-AR expression was quantified by immunofluorescence and RT-qPCR.

SR58611A (10 nM), a preferential $\beta_{3}-A R$ agonist, and purified $\beta_{3}-A B s(25 \mu \mathrm{g} / \mathrm{ml})$ induced a decrease in cell shortening $(-39.71 \pm 4.9 \%(n=10)$ and $-17.06 \pm 3.9 \%(n=10)$ respectively $)$. This effect was significantly inhibited when the cardiomyocytes were preincubated with pertussis toxin $(0.3 \mu \mathrm{g} / \mathrm{ml})$, a $G_{i}$ protein inhibitor $(p<0.05)$. In addition, SR58611A-mediated negative inotropic effect was decreased when cardiomyocytes were preincubated with $\beta_{3}-\mathrm{ABs}(p<0.0001)$. Echocardiography revealed a decrease in the fractional shortening and ejection fraction in rats immunized against $\beta_{1}$-AR and both $\beta_{1}$ - and $\beta_{3}$-AR. However, the study on isolated heart showed a decrease of the isoproterenol-induced lusitropic and inotropic effects in the 3 groups of immunized rats. These systolic and diastolic dysfunctions are correlated with a decrease in the expression of $\beta_{1}$-ARs and an increase of $\beta_{3}$-ARs in rats immunized against the $\beta_{1}-A R$ and an increase of both $\beta_{3}-A R$ and $\beta_{1}$-AR in rats immunized against the $\beta_{3}-A R$. For the first time, these results showed that $\beta_{3}-A B s$ had a $\beta_{3}$-AR partial agonist-like activity which might play a role in the pathogenesis of cardiac dysfunction.
\end{abstract}

() 2015 Elsevier Ltd. All rights reserved.
Abbreviations: AB, antibody; AR, adrenoceptor; $\mathrm{AAB}$, autoantibody; cAMP, cyclic adenosine monophosphate; DCM, dilated cardiomyopathy; DP, developed pressure; $\mathrm{dP} / \mathrm{dt}$, time derivatives of pressure; EDD, left ventricular end-diastolic diameter; EDV, left ventricular end-diastolic volume; $E F$, ejection fraction; ELISA, enzyme-linked immunosorbent assay; eNOS, endothelial nitric oxide synthase; ESD, left ventricular end-systolic diameter; ESV, left ventricular endsystolic volume; FS, fractional shortening; IgG, immunoglobulin; MFI, mean fluorescence intensity; NO, nitric oxide; OD, optical densities; PTX, pertussis toxin; SR58611A, [(RS)-N-[(25)-7-ethoxycarbonylmethoxy-1,2,3,4-tetrahydronapht-2-yl]-(2R)-2(3-chlorophenyl)-2hydroethanamine hydrochloride].

* Corresponding author.

E-mail address: yassine.mallem@oniris-nantes.fr (M.Y. Mallem). 


\section{Introduction}

Idiopathic dilated cardiomyopathy (DCM) is one of the main cause of severe heart failure in young adults. In $60-70 \%$ of cases, the etiology remains poorly understood and growing evidences suggest that the immunity system may play a key role in this disease [1].

$\beta_{1}$-Adrenoceptor (AR) auto-antibodies (AABs) were first detected by ELISA (enzyme-linked immunosorbent) in 26 to $60 \%$ of patients with DCM $[2,3]$. These $\beta_{1}$-AABs are directed against the second extracellular loop of human $\beta_{1}$-AR [4]. In vitro and in vivo studies have shown that $\beta_{1}-A A B s$ induce positive inotropic and chronotropic effects via the $\beta_{1}$-AR/adenylate cyclase/cAMP-dependent protein kinase-A pathway [5-8]. According to Magnusson et al. [7], these $\beta_{1}$-AABs share some properties of partial agonists. They can act as an agonist and activate weakly the $\beta_{1}$-ARs. On the contrary, they can act as an antagonist of the $\beta_{1}$-ARs and block them when the catecholamine levels are high. Furthermore, rat or rabbit immunization with the second extracellular loop of $\beta_{1}$-AR has been reported to be able to induce myocardial dysfunction that may lead to ventricle dilatation similar to that observed in patients $[9,10]$. This effect is considered to result from long-term overstimulation of the $\beta_{1}$-ARs by the $\beta_{1}$-AABs. In agreement with those observations, clinical studies have also found that $\beta_{1}$-AABs suppression by immunoabsorption improves cardiac function of patients with DCM [11,12], strengthening the possibility that $\beta_{1}$-AABs play an important pathophysiological role in the development of this disease.

More recently, circulating $\beta_{3}-A A B s$ directed against the second extracellular loop of the $\beta_{3}-A R$, have also been detected in $30 \%$ of sera from patients with heart failure [13]. A recent study carried out in our laboratory has shown that $\beta_{3}$-AR antibodies $\left(\beta_{3}-A B s\right)$, produced in rats, were able to reduce cardiomyocyte contractility via $\beta_{3}$-AR activation [14]. Nevertheless, very few studies have been done to characterize these auto-antibodies and to evaluate their involvement in DCM.

In addition to $\beta_{1}-A R, \beta_{3}-A R$ is also expressed in the human and animal ventricle myocardium. Its activation was described to induce a negative inotropic effect that involved $G_{i}$ protein/nitric oxide (NO) pathway [15]. Several studies, conducted in failing or non-failing myocardium have reported that the $\beta_{1}$-ARs and $\beta_{3}$ ARs are cross-regulated by interactive compensatory mechanisms [16-19]. The opposed changes in the $\beta_{1}$-AR and $\beta_{3}$-AR-induced myocardial contraction in response to adrenergic stimulation seems to play a role in the worsening of the heart contractility. To the best of our knowledge, it is not known whether similar regulation may occur in response to $\beta_{1}-\mathrm{AABs}$ and $\beta_{3}-\mathrm{AABs}$ that could possess sympathomimetic-like properties. Therefore, the main objective of this study was to determine whether longterm active immunization producing both $\beta_{1}$ - and/or $\beta_{3}$-ABs leads to the development of cardiac dysfunction in Lewis rats. Moreover, considering the $\beta_{3}$-ARs-mediated pertussis toxin (PTX)-sensitive effect in the heart [20] and the $\beta_{3}$-AR agonist-like activity of the $\beta_{3}$-ABs [14], we first investigated, in isolated cardiomyocytes from rabbit, the role of $G_{i}$ proteins in the $\beta_{3}$-ABs-induced cardiac negative inotropy and whether $\beta_{3}-A B s$ may exhibit $\beta_{3}$-AR antagonistic property.

\section{Methods}

\subsection{Animals}

Whole experimental project was validated by local ethics committee for animal experimentation ( $\mathrm{N}^{\circ}$ CEEA.2012.76) and conducted in accordance with "The guide for the care and use of laboratory animals" published by the National Institute of Health
(NIH publication, eight edition, 2010). Nine week-old male Lewis rats from Janvier Labs (Le Genest Saint Isle, France) and New Zealand rabbits (2 kilograms) from Hypharm (Roussay, France) were used for this study. They were housed at constant temperature $\left(22 \pm 2{ }^{\circ} \mathrm{C}\right)$ and subjected to a cycle of dark/light $12: 12 \mathrm{~h}$, with standard chow and drinking water provided ad libitum.

\subsection{Immunization protocol}

Rats were immunized by subcutaneous injections of an antigen dissolved in $1 \mathrm{ml}$ of a solution containing $\mathrm{Na}_{2} \mathrm{CO}_{3}(0.1 \mathrm{M})$ and $\beta$-mercapto-ethanol $1 \%$, conjugated with Freund's adjuvant $(\mathrm{V} / \mathrm{V})$ monthly for 6 months. For that, rats were randomly divided into 4 groups. The first group $(n=10)$ was immunized with the antigen corresponding to the peptidic sequence of the second extracellular loop of human $\beta_{1}$-AR (residues 197-222: H-W-W-R-A-E-S-DE-A-R-R-C-Y-N-D-P-K-C-C-D-F-V-T-N-R; $1 \mathrm{mg} / \mathrm{ml}$ ) synthesized by GeneCust (Dudelange, Luxembourg). The second group $(n=10)$ was immunized with the antigen corresponding to the peptidic sequence of the second extracellular loop of human $\beta_{3}-A R$ (residues 176-200: R-V-G-A-D-A-E-A-Q-E-C-H-S-N-P-R-C-C-S-FA-S-N-M-P; $2 \mathrm{mg} / \mathrm{ml}$ ) (GeneCust, Dudelange, Luxembourg). The third group $(n=10)$ was immunized with both $\beta_{1}$-AR $(1 \mathrm{mg} / \mathrm{ml})$ and $\beta_{3}-A R(2 \mathrm{mg} / \mathrm{ml})$ peptides and the last group $(n=10)$ (adjuvanttreated) received only saline conjugated with Freund's adjuvant $(0.5 \mathrm{ml})$.

\section{3. $\beta_{1}$ - and $\beta_{3}$-adrenergic receptor antibodies detection and purification}

Sera were collected before the first immunization and after 2 , 4 and 6 months of immunization. The evolution of $\beta_{1}$ - and $\beta_{3}-A B$ titers was followed by peptide-based ELISA.

For that, $\beta_{1}$-AR and $\beta_{3}$-AR peptides $(10 \mu \mathrm{g} / \mathrm{ml})$ used for the immunization were dissolved in BIC buffer $\left(\mathrm{Na}_{2} \mathrm{CO}_{3} 0.1 \mathrm{~mol} / \mathrm{l}\right.$; $\mathrm{NaHCO}_{3} 0.1 \mathrm{~mol} / \mathrm{l}$; in distilled water; $\mathrm{pH}$ 9.6) and coated on a 96well microplate (poly NUNC, Denmark) overnight at $4{ }^{\circ} \mathrm{C}$. Serum dilutions $(100 \mu \mathrm{l})$ from $1: 400$ to $1: 51,200$ in PBS-Tween $80-\mathrm{NaCl}$ $0.5 \mathrm{~mol} / \mathrm{l}$, were used to react with the peptides for $1 \mathrm{~h}$ at $37^{\circ} \mathrm{C}$. After washing 3 times with PBS-Tween $80,100 \mu$ l of donkey antirat immunoglobulin (IgG) antibody conjugated with horseradish peroxidase $(1: 50,000$ dilution in PBS-Tween $80-\mathrm{NaCl} 0.5 \mathrm{~mol} / \mathrm{l})$ (Jackson ImmunoResearch, USA) were added to the wells and incubated $1 \mathrm{~h}$ at $37^{\circ} \mathrm{C}$. After 3 washings, $100 \mu \mathrm{l}$ of $3,3^{\prime}, 5,5^{\prime}-$ tetramethylbenzidine (Sigma-Aldrich) were incubated at $37^{\circ} \mathrm{C}$ to detect the bound antibodies. The reaction was stopped after $20 \mathrm{~min}$ of incubation by adding $50 \mu \mathrm{l}$ of sulphuric acid $(0.1 \mathrm{~mol} / \mathrm{l})$. Optical densities (OD) were read at $450 \mathrm{~nm}$ in a microplate reader (TriStar, Berthold Technologies, Bad Wildbad, Germany). The antibody titers were defined by the OD values.

IgG fractions were purified from sera collected after 6 months of immunization using the Proteus Protein G kit (AbD Serotec, Colmar, France) in compliance with the manufacturer's instructions. Purified antibody concentrations were determined by the bicinchoninic acid protein assay (Uptima, Interchim, Montluçon, France).

\subsection{Functional characterization of IgGs containing $\beta_{3}$-adrenergic receptor antibodies}

The functionality of purified $\beta_{3}$-ABs was evaluated on ventricular cardiomyocytes isolated in healthy rabbit, which is known to express functional $\beta_{3}$-ARs [21]. Briefly, rabbits were anesthetized with pentobarbitone $(54 \mathrm{mg} / \mathrm{kg}$ IV) and heparinized $(2500 \mathrm{IU} / \mathrm{kg}$ IV). Cardiomyocytes were isolated by perfusion $(7 \mathrm{ml} / \mathrm{min})$ of heart mounted on a Langendorff apparatus with $1 \mathrm{mg} / \mathrm{ml}$ collagenase type II (Worthington, Lakewood, NI, USA) and $0.04 \mathrm{mg} / \mathrm{ml}$ protease 
type XIV (Sigma-Aldrich, France) $\left(30 \mu \mathrm{M} \mathrm{CaCl}_{2}\right)$ for 20 min. After gentle manual stirring, cardiac cells were progressively exposed to increasing $\mathrm{Ca}^{2+}$ concentrations in $100 \% \mathrm{O}_{2}$ aerated Tyrode solution ( $\mathrm{NaCl} 137 \mathrm{mM}$; KCl $5.4 \mathrm{mM}$; $\mathrm{MgCl}_{2} 1.2 \mathrm{mM}$; $\mathrm{Na}_{2} \mathrm{HPO}_{4} 1.2 \mathrm{mM}$; HEPES $20 \mathrm{mM}$; D-glucose $10 \mathrm{mM}$; pH 7.4). Cardiomyocytes were plated on poly-L-lysine-coated $35 \mathrm{~mm}$ culture dishes and perfused at a flow rate of $3-4 \mathrm{ml} / \mathrm{min}$ with Tyrode solution $\left(1.8 \mathrm{mM} \mathrm{CaCl}_{2}\right.$ ) at $37^{\circ} \mathrm{C}$. Cells were stimulated by an electric field $(1 \mathrm{~Hz})$ at $9 \mathrm{~V}$ and cell shortening was recorded using a video-imaging system (Coyote Bay Instruments, Manchester, NH, USA). Imaging analysis was performed using Matrox Inspector software (Coyote Bay Instruments, Manchester, NH, USA). Myocytes selected for data analysis presented clear striation, rod-shaped form and a stable diastolic length at baseline. Ten consecutive heart contractions were used for the analysis.

\subsection{Echocardiography}

At 6 months of immunization, rats were lightly anaesthetized with $1-1.5 \%$ isoflurane until the heart rate stabilized to $350-400$ beats per minute. Transthoracic echocardiography was realized using a high frequency ultrasound imaging system (MyLab70 XVG, Esaote, Indianapolis, IN) with a linear $18 \mathrm{Mhz}$ transducer. The focal length used was adjusted around $10 \mathrm{~mm}$. To identify whether the immunization leads to the development of functional and structural cardiac dysfunctions, fraction shortening (FS), ejection fraction (EF), left ventricular end-systolic diameter (ESD), left ventricular end-diastolic diameter (EDD), left ventricular end-systolic volume (ESV) and left ventricular end-diastolic volume (EDV) were determined using M-Mode recordings in the short axis of the heart. ESV and EDV were calculated using the monoplane area-length method: $V=8 \times A^{2} / 3 \pi L$. FS and EF were respectively calculated using the formulas $F S=[(E D D-E S D) / E D D] \times 100$ and $\mathrm{EF}=[(\mathrm{EDV}-\mathrm{ESV}) / \mathrm{EDV}] \times 100$. Three consecutive heart cycles were measured and the average used for analysis.

\subsection{Ex vivo cardiac function}

At 6 months of immunization, half of immunized rats were anaesthetized by intraperitoneal injection of pentobarbitone $(54 \mathrm{mg} / \mathrm{kg})$ and heparinized $(2500 \mathrm{IU} / \mathrm{kg})(n=5$, for each group). The heart was immediately removed and placed into ice-cold Krebs-Henseleit buffer $(\mathrm{NaCl} 118.3 \mathrm{mM}$; $\mathrm{KCl} 4.7 \mathrm{mM}$; $\mathrm{MgSO}_{4}, 7 \mathrm{H}_{2} \mathrm{O} 1.2 \mathrm{mM} ; \mathrm{KH}_{2} \mathrm{PO}_{4} 1.2 \mathrm{mM}$; $\mathrm{NaHCO}_{3} 20 \mathrm{mM}$; EDTA $0.016 \mathrm{mM}$; Glucose $11.1 \mathrm{mM}$; $\mathrm{CaCl}_{2} 2.5 \mathrm{mM}$; pH 7.4). The aorta was rapidly cannulated and the heart retrogradely perfused by a non-recirculating-Langendorff technique at a constant flow of $10 \mathrm{ml} / \mathrm{min}$ in continuously gassed $\left(95 \% \mathrm{O}_{2} / 5 \% \mathrm{CO}_{2}\right)$ prewarmed $\left(37^{\circ} \mathrm{C}\right) \mathrm{KH}$ buffer. To determine left ventricular function, a latex balloon was inserted into the left ventricle through the mitral valve and filled until the left ventricular end-diastolic pressure reached a value of $5 \mathrm{~mm} \mathrm{Hg}$. An equilibration period of at least $30 \mathrm{~min}$ was required to ensure the stability of recorded parameters before any addition of molecule. For each immunized rat, systolic, diastolic, developed pressures and the heart rate were recorded initially and after the addition of (-)-isoproterenol hydrochloride (100 nM). Left ventricular developed pressure (DP) was determined as the difference between left ventricular systolic pressure and left ventricular end-diastolic pressure. Time derivatives of pressure were calculated electronically during contraction ( $\mathrm{dP} / \mathrm{dT}$ max) and relaxation (dP/dT min) using a Powerlab 8/30 Data Acquisition system and analyzed by LabChart ${ }^{\circledR}$ Pro software (V7, ADInstruments, France).

\subsection{Real time quantitative RT-PCR}

The other half of immunized rats ( $n=5$, for each groups) were used to perform real time RT-qPCR to evaluate the effect of immunizations on the mRNA levels of $\beta_{1}-A R, \beta_{2}-A R$ and $\beta_{3}-A R$ in the heart.Briefly, heart fragments were rapidly frozen in liquid nitrogen and stored at $-80^{\circ} \mathrm{C}$. Frozen samples were dissolved in $1.5 \mathrm{ml}$ of TRIzol ${ }^{\circledR}$ Reagent and ground to powder in a potter, according to manufacturer's instructions (Life Technologies, France). Total RNA were obtained after chloroform extraction and isopropanol precipitation and resuspended in $50 \mu \mathrm{l}$ of RNase-free water, heated at $58^{\circ} \mathrm{C}$ and stored at $-20^{\circ} \mathrm{C}$. The total RNA integrity was checked by agarose gel eletrophoresis. Total RNA concentrations, 260/280 and 260/230 ratios were determined by spectrophotometry (Nanodrop 2000, Thermo Scientific, France).

To remove any contaminating genomic DNA, a DNase digestion step (DNase I recomb, Roche Diagnostics France, France) was carried out according to manufacturer's instructions. DNA-free total RNA were recovered in $20 \mu \mathrm{l}$ of RNase-free water. Absence of contaminating DNA fragments was again verified with a sensitive GAPDH PCR (primers in Table 1) and with agarose gel electrophoresis. DNA-free total RNA concentrations and DO ratios were then determined by spectrophotometry.

Each sample underwent the following reverse transcription step: $1 \mu \mathrm{g}$ of DNA-free total RNA was used in $20 \mu \mathrm{l}$ total of mix solution based on the Superscript IV Reverse-Transcriptase kit (Life Technologies, France), with both $1 \mu \mathrm{l}$ of Random Primers $(3 \mu \mathrm{g} / \mu \mathrm{l})$ and $1 \mu$ l of Oligo(dT) $)_{20}$ Primer $(50 \mu \mathrm{M})$ for RT. Retrotranscribed RNA efficiency was further validated with a new GAPDH PCR and with agarose gel electrophoresis.

Real time PCR reactions were set in $15 \mu$ l with 5 X HOT FIREPol ${ }^{\circledR}$ EvaGreen ${ }^{\circledR}$ qPCR Mix (high ROX) (Solis BioDyne, Riia, Estonia), including either $5 \mu$ l of diluted cDNA (1:6) and $1 \mu$ l of each primers $(10 \mu \mathrm{M})$. After an initial denaturation/DNA polymerase activation step of $15 \mathrm{~min}$ at $95^{\circ} \mathrm{C}$, the PCR forty cycles consisted of $10 \mathrm{~s}$ at $95^{\circ} \mathrm{C}$ denaturation step and of $1 \mathrm{~min}$ at $60^{\circ} \mathrm{C}$ (for ADRB-1and ADRB-2primers) or $61^{\circ} \mathrm{C}$ (for ADRB-3 and eNos primers) hybridization/elongation step. Melting curves were produced to confirm the presence of a single gene specific peak and the absence of primer dimers. The quantification of gene expression was based on the $2^{-\Delta \Delta \mathrm{Ct}}$ method [27]. Briefly, the mean Ct value of the control housekeeping gene $\beta$-actin was subtracted from mean threshold cycle values of duplicates for each interest mRNA. The difference in the mean $\Delta C$ t values between adjuvant-treated rats and $\beta$-immunized rats allows the calculation of relative levels of induced or repressed expression of the interest gene.

\subsection{Immunofluorescence and quantification of $\beta$-adrenergic receptor expression}

Rat heart used for the RT-qPCR were also used to quantify $\beta$-AR expression in the heart ( $n=5$, for each groups). For that, immediately after the excision, heart was transversally sectioned and the middle section was post-fixed by incubation in $4 \%$ phosphatebuffered paraformaldehyde ( $\mathrm{pH} 7.4$ ) for $4 \mathrm{~h}$ at $4{ }^{\circ} \mathrm{C}$. After 3 washings with PBS solution, it was cryoprotected by overnight incubation in PBS containing $20 \%$ sucrose. Then, heart section was embedded in transverse position in Tissue Tek OCT medium and immediately frozen by immersion in liquid isopentane. Frozen sections $(8 \mu \mathrm{m}$ thick) for immunohistochemical analysis were thawed and submerged for $5 \mathrm{~min}$ in acetone at $4{ }^{\circ} \mathrm{C}$ and nonspecific antigen binding was blocked by incubating sections for $1 \mathrm{~h}$ in a PBS solution containing $0.3 \%$ Triton $100 \mathrm{X}$ and $2 \%$ bovine serum albumin (Sigma) following by $1 \mathrm{~h}$ at $37^{\circ} \mathrm{C}$ incubation in the blocking buffer with a rabbit polyclonal antibody against $\beta_{1}-A R(1: 50$, Santa Cruz Biotechnology Inc., CA, USA) or a goat polyclonal antibody against $\beta_{3}-A R$ 
Table 1

Oligonucleotide primers used in the study. Oligonucleotide sequence orientations are indicated as forward (Fw) and reverse (rv).

\begin{tabular}{|c|c|c|c|}
\hline Primer name & $\begin{array}{l}\text { Accession num- } \\
\text { ber/publication }\end{array}$ & Sequence $\left(5^{\prime}-3^{\prime}\right)$ & Ampliconsize (bp) \\
\hline ADRB-1-Fw & NM_012701 & CTGCTACAACGACCCCAAGTG & 120 \\
\hline ADRB-1-Rv & {$[22]$} & AACACCCGGAGGTACACGAA & \\
\hline ADRB-2-Fw & NM_012492 & CTCCTTAACTGGTTGGGCTATG & 127 \\
\hline ADRB-2-Rv & Our design & TCCCATAGGTTTTCGAAGAAGA & \\
\hline ADRB-3-Fw & NM_013108 & GCCGAGACTACAGACCATAACCA & 79 \\
\hline ADRB-3-Rv & {$[23,24]$} & CATTACGAGGAGTCCCACTACCA & \\
\hline eNos-Fw & NM _021838 & AGCTGGATGAAGCCCGGTGAC & 60 \\
\hline eNos-Rv & {$[25]$} & CCTCGTGGTAGCGTTGCTGA & \\
\hline B-Act-Fw & NM_007393 & TTGCTGACAGGATGCAGAAG & 86 \\
\hline B-Act-Rv & Our design & GTACTTGCGCTCAGGAGGAG & \\
\hline GAPDH-Fw & AF106860 & ACTGGCGTCTTCACCACCATGGAGAAGGCT & 720 \\
\hline GAPDH-Rv & {$[26]$} & CTCCTTGGAGGCCATGTAGGCCATGAGGTC & \\
\hline
\end{tabular}

(1:100, Santa Cruz Biotechnology Inc., CA, USA) for 1 h at $37^{\circ} \mathrm{C}$. After being washed in PBS, the sections were incubated with the secondary antibody, AlexaFluor 555-conjuguated donkey anti-rabbit (1:300, Life Technologies, Saint Aubin, France) or donkey anti-goat (1:300, Life Technologies, Saint Aubin, France) during $1 \mathrm{~h}$ at room temperature. After being washed, the sections were stained with nuclear dye DRAQ5 (1/1000, BioStatus, Shepshed, United Kingtom) and mounted in Mowiol (Calbiochem, San Diego, CA, USA). The immunolabeled sections were scanned serially using the helium neon laser $(543 \mathrm{~nm})$ to observe Alexa fluor 555 ( $\beta$-AR immunolabellings) and with a helium neon laser $(633 \mathrm{~nm})$ to observe DRAQ5 signals (nuclei). Each image was recorded in a separated channel (channel red for Alexa fluor 555 and channel blue for DRAQ5) and overlayed. Acquisitions were performed by using a confocal microscope (Nikon, C1, Champigny-sur-Marne, France). Image analysis were performed to evaluate $\beta$-AR expression level in the heart ventricle of immunized rats by using Fiji software. Mean Fluorescence Intensity (MFI) values for $\beta$-AR immunolabelling in each condition were acquired from 5 different fields of immunolabeled ventricule heart sections by section with 5 rats by conditions. Finally, analyses were performed at least on $550 \pm 100$ cardiac fibers by animal. The same threshold was used to measure the sum intensity fluorescence of $\beta$-AR immunolabelling in each section and the MFI was reported to total area of analyzed section.

\subsection{Drugs}

(-)-Isoproterenol hydrochloride, L-748337 hydrate, pertussis toxin from Bordetella pertussis were obtained from Sigma-Aldrich (France). SR58611A [(RS)-N-[(25)-7-ethoxycarbonylmethoxy-1,2,3,4-tetrahydronapht-2-yl]-(2R)-2(3-chlorophenyl)-2hydroethanamine hydrochloride] was a generous gift from Sanofi group (France). All drugs were prepared in distilled water with the exception of SR58611A that was dissolved in ethanol. Sodium pentobarbital solution was purchased from CEVA Santé Animale (Libourne, France) and heparine choay from Sanofi Aventis (Paris, France).

\subsection{Statistical analysis}

Results were expressed as a mean \pm SEM where $n$ represents the number of rats or rabbits used for the study. Statistical differences in comparison with the adjuvant-treated rats were evaluated using unpaired Student's $t$ test with Prism ${ }^{\circledR}$ software V.5. The conditions for the $t$-test were tested with a Kolmogorov-Smirnov' test for the Gaussian distribution and with an F-test for the homogeneity of variances. For the ex vivo study, differences were determined using nonparametric Mann-Whitney test and for the immunoflu- orescence analysis using a univariate Student's $t$ test (R software V3.0.1). A value for $p<0.05$ was considered statistically significant.

\section{Results}

\section{1. $\beta$-adrenoceptor antibody production and characterization}

$\beta_{1}-A B s$ and $\beta_{3}-A B s$ were generated by immunizing rats for 6 months and their respective immunoreactivities were determined by ELISA. Two months after the first immunization, we observed a high production of specific $\beta_{1}$-ABs in rats immunized with $\beta_{1}$-AR or $\beta_{1}$ - and $\beta_{3}$-AR peptides (Fig. 1). After the 6 months of immunization, $\beta_{1}-A B$ titers were still high and stable compared to the low level of production in antibody titers in $\beta_{3}$-AR-immunized rats and adjuvant-treated rats (OD at 6 months: $2.09 \pm 0.24$ and $2.30 \pm 0.21$ for $\beta_{1}$-AR and $\beta_{1}$ - and $\beta_{3}$-AR-immunized rats respectively versus $0.07 \pm 0.005$ and $0.08 \pm 0.03$ for adjuvant-treated rats and $\beta_{3}$-ARimmunized rats respectively). In the same way, we observed a high increase of $\beta_{3}-A B$ titers in both $\beta_{3}$-AR-immunized rats and $\beta_{1}$ - and $\beta_{3}$-AR-immunized rats after 6 months of immunization compared with the $\beta_{1}$-AR-immunized rats and adjuvant-treated rats (OD at 6 months: $1.37 \pm 0.26$ and $2.28 \pm 0.18$ for $\beta_{3}$-AR and $\beta_{1}$ - and $\beta_{3}$ AR-immunized rats respectively versus $0.07 \pm 0.006$ and $0.14 \pm 0.02$ for adjuvant-treated rats and $\beta_{1}$-AR-immunized rats respectively) (Fig. 1). The data highlighted antibody specificity for their antigen and the lack of cross-reactivity between the two subtypes of $\beta$-AR.

\subsection{Negative inotropic effect of $\beta_{3}$-adrenoceptor antibody}

To determine whether $\beta_{3}-A B s$ exhibit an agonistic effect as it was already described for $\beta_{1}$-ABs [8], we measured the effect of $\beta_{3}-A B$ perfusion on electrically field-stimulated cell shortening. $\beta_{3}-A B$ s induced a decrease of cell shortening $(-17.06 \pm 3.9 \%$, $n=10)$ and this effect was significantly inhibited in presence of PTX $(0.3 \mu \mathrm{g} / \mathrm{ml})$, a $G_{i}$ protein inhibitor, and L-748337 $(1 \mu \mathrm{M})$, a selective $\beta_{3}$-AR antagonist $(\rho<0.05)$ (Fig. 2a). SR58611A ( $\left.10 \mathrm{nM}\right)$, a preferential $\beta_{3}$-AR agonist produced also a significant decrease of cell shortening which was stronger than that induced by $\beta_{3}-\mathrm{ABs}$ $(-39.71 \pm 4.9 \%, n=10$ and $-3.88 \pm 3.4 \%, n=7$, respectively). This negative inotropic effect was not observed when cardiomyocytes were perfused with the antibodies from adjuvant-treated rats.

Then, assuming that $\beta_{3}$-ABs behaved as partial $\beta_{3}$-AR agonists, we tested their ability to exhibit $\beta_{3}$-AR antagonistic properties. Incubation of rabbit cardiomyocytes for $2 \mathrm{~h}$ with $\beta_{3}-\mathrm{ABs}(25 \mu \mathrm{g} / \mathrm{ml})$ significantly reduced the SR58611A-induced negative inotropy $(-7.22 \pm 3.8 \%, n=4)$ in comparison with antibodies from ajduvanttreated rats $(-27.47 \pm 8.23 \%, n=7)$ (Fig. $2 \mathrm{~b}$ ). 
a.

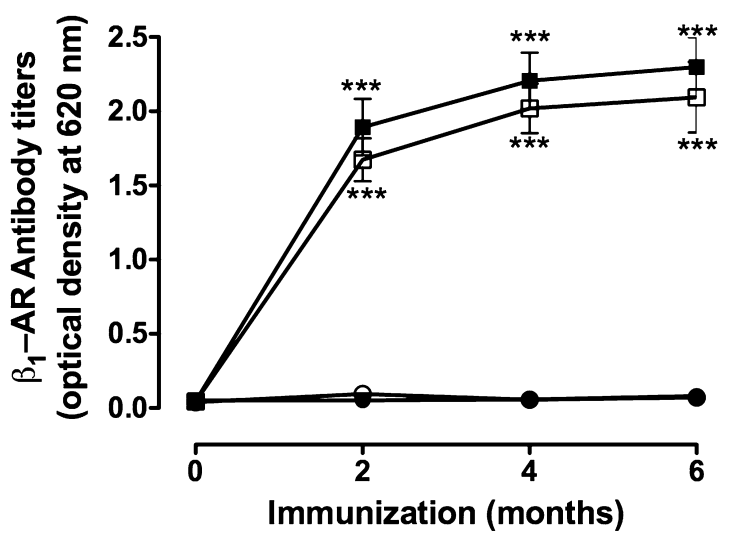

b.

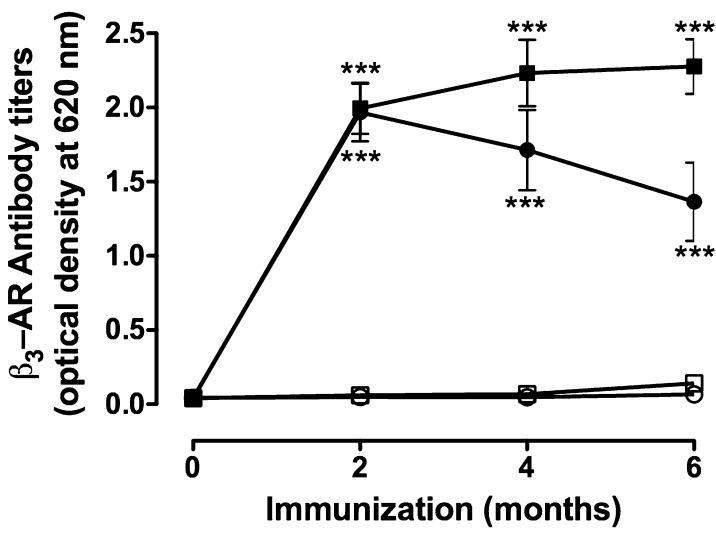

$\begin{array}{ll}\text { O } & \text { Adjuvant-treated rats }(n=10) \\ \text { 口 } & \beta_{1} \text {-AR-immunized rats }(n=10) \\ \text { - } & \beta_{3} \text {-AR-immunized rats }(n=10) \\ \text { - } & \beta_{1} \text {-and } \beta_{3} \text {-AR-immunized rats }(n=10)\end{array}$

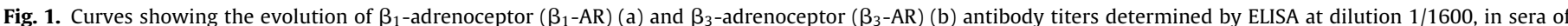

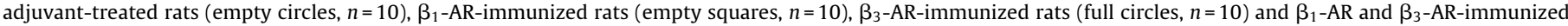

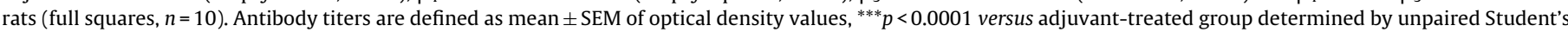
$t$-test at the different times.

a.

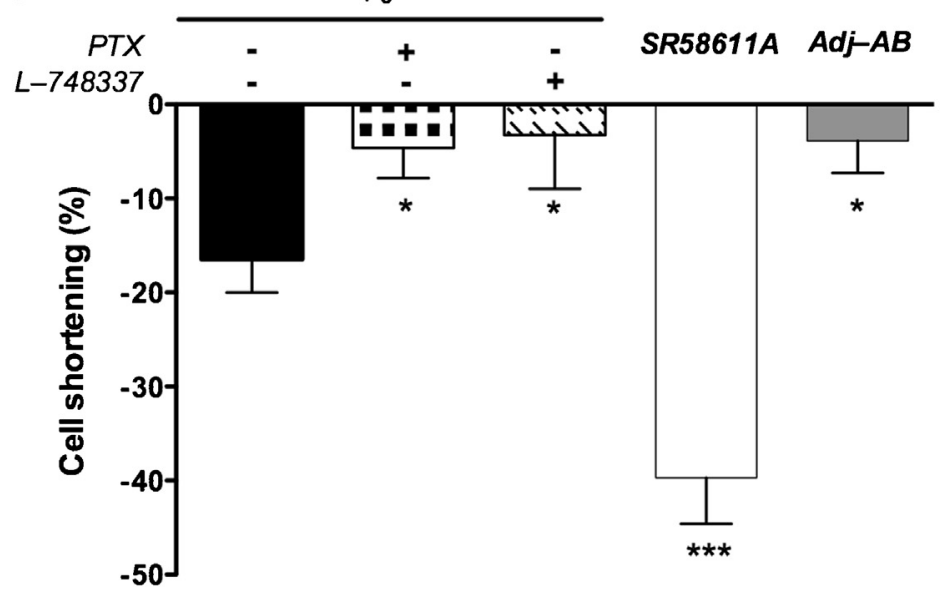

b.

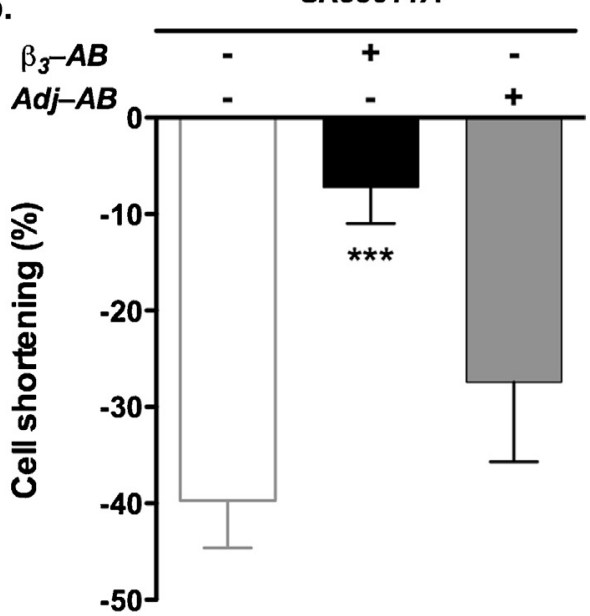

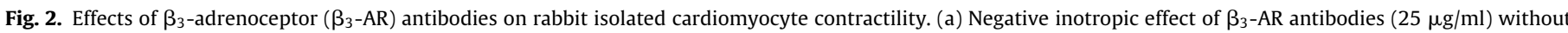

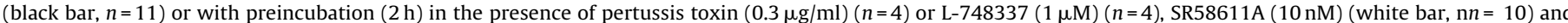

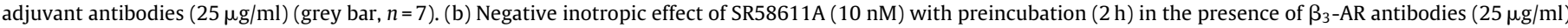

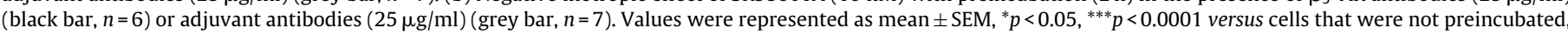
determined by unpaired Student's $t$-test.

\subsection{Influence of immunizations on cardiac function-in vivo study}

To evaluate whether the different immunizations were able to impact the cardiac contractility, we performed echocardiography. Data indicated that $\mathrm{EF}$ and $\mathrm{FS}$ were decreased in rats immunized during 6 months with $\beta_{1}$-AR (EF: $-3.7 \%$ and $\mathrm{FS}:-5.1 \%$ versus adjuvant-treated rats) or both $\beta_{1 / 3}$-AR peptides (EF: $-5.6 \%$ and FS: $-7.8 \%$ versus adjuvant-treated rats) compared to adjuvanttreated rats (EF: $77.50 \pm 0.47 ;$ FS: $47.53 \pm 0.48$ ) (Fig. 3). The EDD and ESD were not altered by the immunization in $\beta_{1}$-AR-immunized rats while in $\beta_{1 / 3}$-AR-immunized rats both EDD and ESD were increased (EDD: $+4.02 \%$ and ESD: $+11.13 \%$ versus adjuvant-treated rats) (Fig. 3). In contrast, immunization with only $\beta_{3}$-AR peptide did not alter the EF and FS but increased the EDD $(+2.73 \%$ versus adjuvant-treated rats) (Fig. 3c). Moreover, systolic blood pressure was not modified during the 6 months of immunization in the 4 groups of rats (data not shown) suggesting that these observed effects on cardiac contractility were not due to changes in arterial pressure and did not impact blood pressure.

\subsection{Influence of immunizations on cardiac function-ex vivo study}

The influence of chronic immunization on left ventricular contractility was also evaluated ex vivo using a non-recirculatingLangendorff technique. For each group of rats, systolic, diastolic, developed pressures and the heart rate were recorded under 
a.

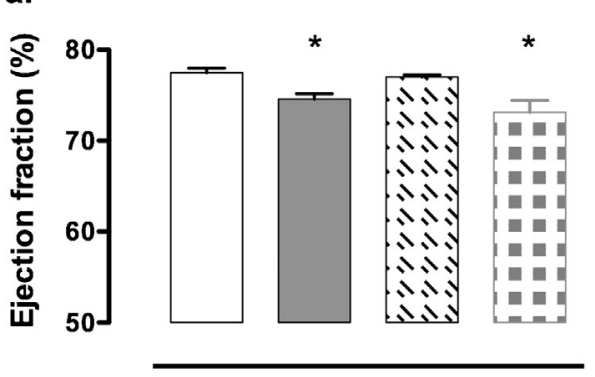

C.

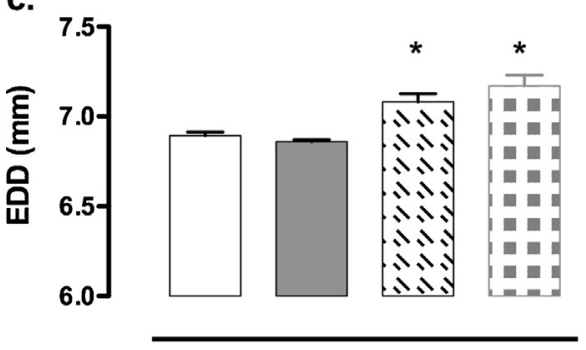

Adjuvant-treated rats $(n=5)$ $\beta_{1}-$ AR-immunized rats $(n=5)$ b.

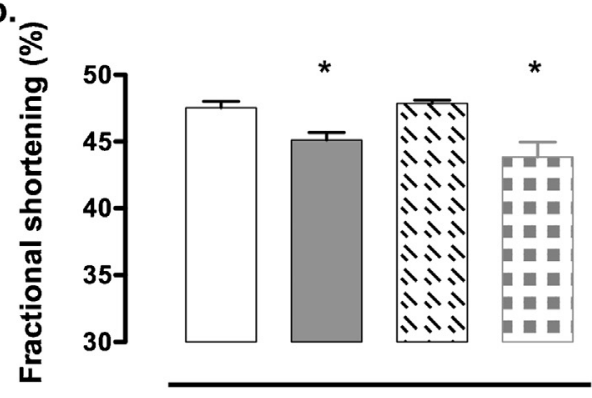

d.

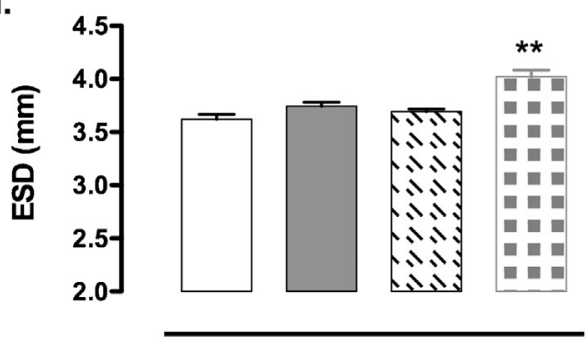

1. $\beta_{3}$-AR-immunized rats $(n=5)$

E. $\beta_{1}$-and $\beta_{3}$-AR-immunized rats $(n=5)$

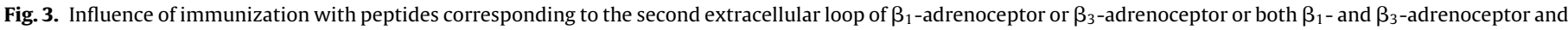

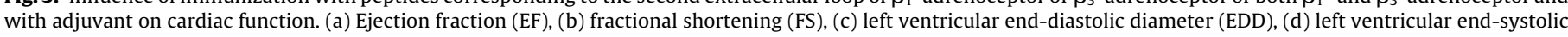
diameter (ESD). Values were represented as mean $\pm \mathrm{SEM},{ }^{*} p<0.05,{ }^{* *} p<0.001$ versus adjuvant-treated rats, $n=5$ rats for each groups.

basal conditions and after the addition of isoproterenol (100 nM). The data showed that isoproterenol increased the heart rate, the maximal and minimal first derivative of change in pressure over time $(\mathrm{dP} / \mathrm{dt}(\mathrm{max} / \mathrm{min}))$ and the developed pressure of hearts from adjuvant-treated rats. These effects were decreased in hearts from rats immunized with $\beta_{1}$-AR or $\beta_{3}$-AR or $\beta_{1 / 3}$-AR peptides (Fig. 4). Given that heart contractility at baseline was not altered by immunizations (data not shown), these findings revealed that immunizations with a $\beta$-AR peptide ( $\beta_{1}$-AR and/or $\beta_{3}-\mathrm{AR}$ ) decreased the isoproterenol-induced lusitropy ( $\mathrm{dP} / \mathrm{dt} \mathrm{min}$ ) and the inotropy parameters ( $\mathrm{dP} / \mathrm{dt}$ max and developed pressure). We showed that $\beta_{1}$-AR and $\beta_{3}$-AR-immunizations had a similar outcome on heart function.

\subsection{Influence of immunizations on $\beta$-adrenoceptor mRNA and expression}

RT-qPCR were carried out to determine whether chronic immunizations modified cardiac mRNA level of $\beta$-ARs. The data have shown that $\beta_{1}$-AR-immunization induced a slight increase of $\beta_{1}$-AR transcripts compared to adjuvant-treated rats whereas $\beta_{2}-A R, \beta_{3}-A R$ and eNOS (endothelial NO synthase) transcripts seemed to not be changed. A similar transcription profile was also observed in $\beta_{1} / \beta_{3}$-AR-immunized. The $\beta_{3}$-AR-immunization induced a slight increase of $\beta_{1}-A R, \beta_{3}-A R$ transcripts but no modification of the $\beta_{2}$-AR and eNOS mRNA levels (Fig. 5). To determine the expression profile of the $\beta_{1}$-AR and $\beta_{3}$-AR proteins on heart, immunofluorescence labeling were carried out. First, the membrane localization of $\beta$-ARs was checked by performing a co-labeling of $\beta$-AR/Dystrophin $B$ to confirm the antibody specificity. The co-labeling results showed that $\beta_{1}$-ARs and $\beta_{3}$-ARs were expressed at the cell membrane in heart of adjuvant-treated rats (Fig. 6). The data on expression $\beta_{1}$-AR and $\beta_{3}$-AR profile were generally in accordance with the observa- tions on mRNA levels (Fig. 7). The $\beta_{1}$-AR-immunization reduced $\beta_{1}$-AR expression $(-11.89 \pm 9.74 \% ; n=5)$ but increased that of $\beta_{3}$-ARs (+51.42 $\pm 15.93 \% ; n=5$ ) whereas the $\beta_{3}$-AR-immunization increased both $\beta_{1}$-AR and $\beta_{3}$-AR expressions $(+89.06 \pm 20.69 \%$; $n=5$ and $123.60 \pm 28.04 \% ; n=5$, respectively).

\section{Discussion}

The present study clearly demonstrated that $\beta_{3}$-ABs purified from $\beta_{3}$-AR-immunized rats induced a $\beta_{3}$-AR partial agonist-like activity on isolated rabbit cardiomyocytes. In addition, by ex vivo approach, we revealed that rat immunizations for 6 months producing functional $\beta_{1}-\mathrm{ABs}$ and/or $\beta_{3}-\mathrm{ABs}$ led to the development of both systolic and diastolic dysfunctions.

In this work, peptide-based ELISA method has allowed to test the specificity of the $\beta_{3}$-ABs for the second extracellular loop of the $\beta_{3}$-AR. Immunized rats have produced high concentration of $\beta_{1}$-AR and $\beta_{3}$-AR IgG-like ABs. In addition, $\beta_{3}$-ABs did not cross-react with $\beta_{1}$-ARs that share a high degree of structural and biochemical similarities with $\beta_{3}$-ARs. According to Bornholz et al. [2], $\beta_{1}$-AABs from patients with DCM preferentially recognize a native $\beta_{1}$-AR conformation. Therefore, the peptide-based ELISA method seems not to be the most appropriate method to detect human $\beta_{1}$-AABs. However, in this present work, the use of peptides to detect antibodies generated by immunization in rats was not an issue because we used the same peptides for both the immunization and the detection of antibodies.

We previously showed that $\beta_{1}$-ABs produced by immunization of rats with $\beta_{1}$-AR peptide induced a positive inotropic effect [8]. In order to test whether $\beta_{3}$-ABs possess also biological activity, we performed inotropic study on cardiomyocytes isolated from adult healthy rabbit. The $\beta_{3}$-ABs-induced pertussis toxin-sensitive effect strongly suggests that the $\beta_{3}-A B s$ are endowed with negative inotropic action on cardiomyocytes that involves $\beta_{3}-A R / G_{i}$ protein 

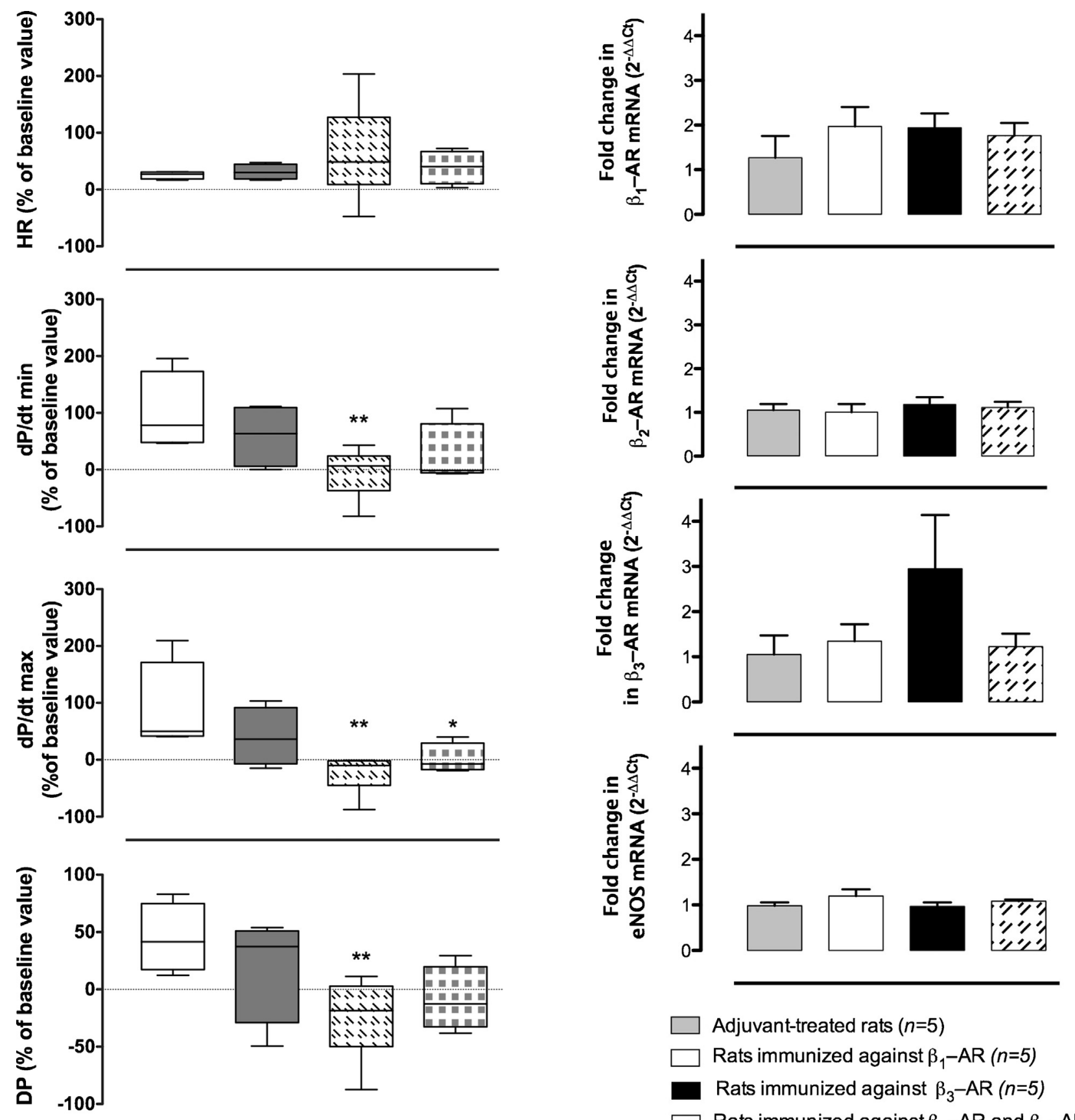

Adjuvant-treated rats $(n=5)$

Rats immunized against $\beta_{1}-\operatorname{AR}(n=5)$

Rats immunized against $\beta_{3}-\mathrm{AR}(n=5)$

Q.) Rats immunized against $\beta_{1}-\mathrm{AR}$ and $\beta_{3}-\mathrm{AR}(n=5)$

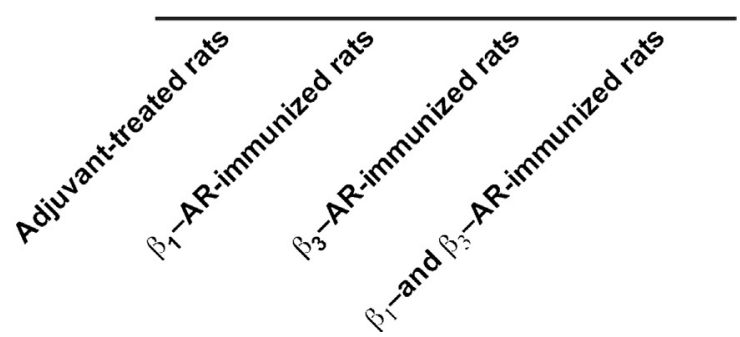

Fig. 5. Comparative analysis of the mRNA levels of $\beta_{1}$-adrenoceptor (AR), $\beta_{2}-A R, \beta_{3}$ AR and endothelial nitric oxide synthase (eNOS) in heart from adjuvant-treated rats (grey bars), $\beta_{1}$-AR-immunized rats (black bars), $\beta_{3}$-AR-immunized rats (white bars) and both $\beta_{1}$ - and $\beta_{3}$-AR-immunized rats (stripped bars). Values were expressed as $2^{-\Delta \Delta \mathrm{Ct}}$ using $\beta$-actin as a housekeeping gene and were represented as mean $\pm \mathrm{SEM}$.

pathway. In addition, the decrease of SR58611-induced negative inotropy after the incubation of cardiomyocyte in presence of $\beta_{3}$ ABs indicates that the $\beta_{3}$-ABs can also antagonize the $\beta_{3}$-ARs. Taken together, these results are in favor of a partial agonist-like activity of the $\beta_{3}-A B s$ on heart.

The immunization protocol used to produce specific antibodies behaving like AABs has been already applied to study the cardiostimulating effects of $\beta_{1}$-AABs in rat and rabbit $[8,28]$. Our findings agree with a recent study showing that $\beta_{3}$-AABs purified from patients with DCM induced negative inotropic and negative chronotropic effects on rat neonatal cardiomyocytes [29]. Therefore, it might be argued that $\beta_{3}-A B s$ as well as $\beta_{1}-A B s$ would not 

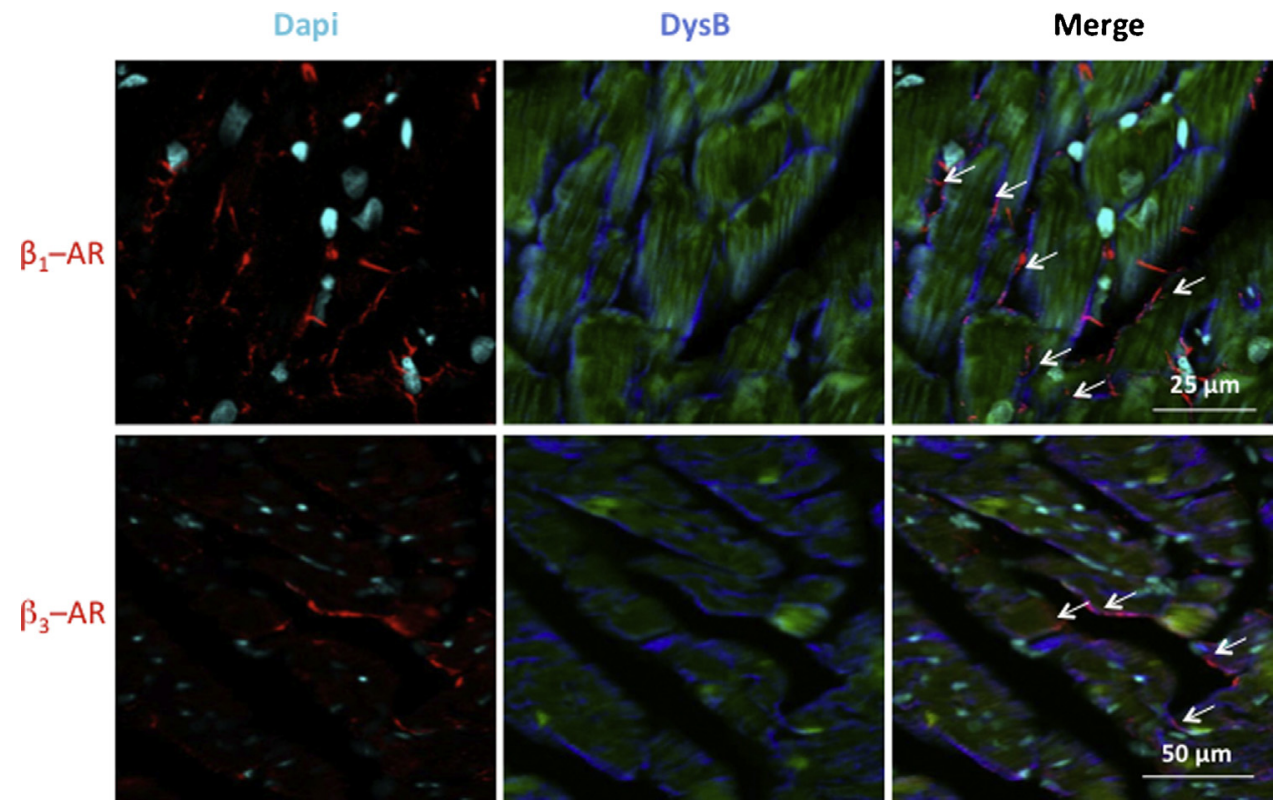

Fig. 6. Immunofluorescent co-labeling of $\beta_{1}$-adrenoceptors (ARs) or $\beta_{3}$-ARs and dystrophin $B$ in heart from adjuvant-treated rats.

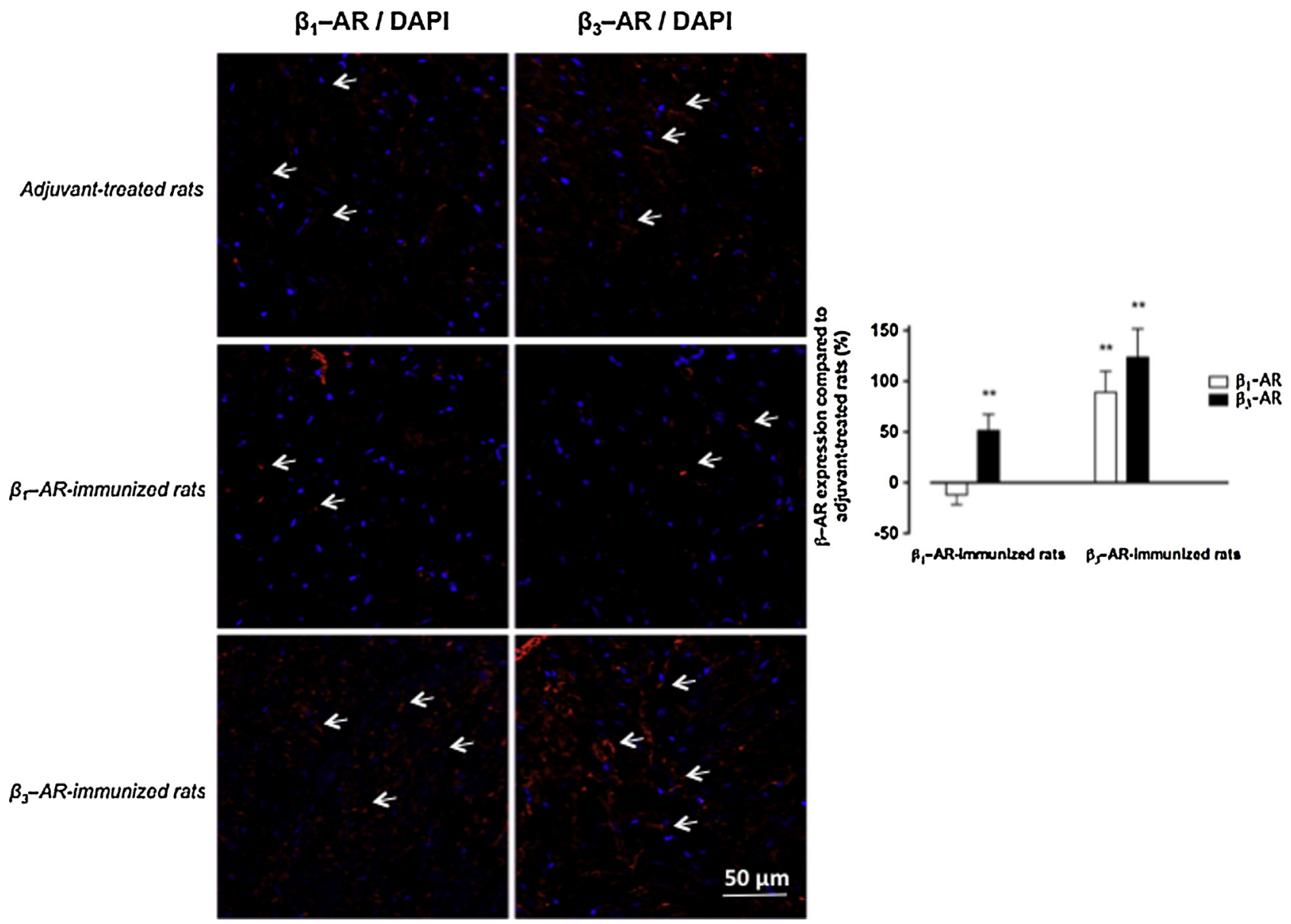

Fig. 7. Influence of immunization with peptides corresponding to the second extracellular loop of $\beta_{1}$-adrenoceptor $(A R)(n=5)$ or $\beta_{3}-A R(n=5)$ on $\beta_{1}-A R\left(w h i t e\right.$ bars) and $\beta_{3}-$ AR (black bars) expressions in heart compared to adjuvant-treated rats. Values were represented as mean \pm SEM of percentage increase of fluorescence from adjuvant-treated rats. Values were represented as mean $\pm \mathrm{SEM},{ }^{* *} p<0.001$, determined by univaried Student's $t$-test. 
be just a biomarker, as stated by Miao et al. [30], but would have a functional role which needs more thorough investigation.

To evaluate whether circulating $\beta_{1}-A B s$ and $\beta_{3}-A B s$ having agonistic properties were able to impact the myocardial function, rats were immunized during 6 months with $\beta_{1}$-AR and/or $\beta_{3}$-AR peptides.

As it was already described [31,32], our results showed a slight but a significant decrease of fractional shortening and ejection fraction in rats immunized 6 months with the $\beta_{1}$-AR peptide without modifications of systolic arterial pressure, assessed by tail cuff method. These observations were concordant with previous studies showing that left ventricle dysfunctions appeared after 6 months of immunization against $\beta_{1}$-AR $[9,10]$. However, in our study, the inability of $\beta_{1}$-ABs to induce the development of left ventricle dilatation (i.e., no modification of end-systolic and -diastolic diameters) is likely linked to the fact that 6 months of immunization is not sufficient to observe noticeable alteration in myocardial contractility. In accordance with echocardiographic results, our ex vivo findings also revealed both systolic and diastolic dysfunctions in rats immunized with the $\beta_{1}$-AR or both $\beta_{1}$ - and $\beta_{3}$-AR peptides. These dysfunctions were characterized by a reduction of isoproterenol-induced inotropy and lusitropy that likely involved an impairment of global $\beta$-AR reactivity (i.e., modification in $\beta$-AR expression or $\beta$-ARs-linked mechanisms). In line with this hypothesis, the quantification of $\beta-A R$ expression by immunofluorescence revealed a downregulation of $\beta_{1}$-ARs and an up-regulation of $\beta_{3}$-ARs in $\beta_{1}$-AR-immunized rats when compared with the adjuvant-treated rats in the left ventricle. This pattern of regulation was already reported to be involved in the alteration of myocardial contractility and was similar to that observed in patients with DCM [16,17]. Surprisingly, the $\beta_{1}$-AR mRNA was not decreased and the $\beta_{3}-A R$ mRNA was not significantly increased in $\beta_{1}$-AR-immunized rats. The reason of this discrepancy is not readily apparent in our study, but the change in the post-transcriptional or in the posttranslational mechanisms could explain the lack of correlation between mRNA and protein expressions which remains to be elucidated.

One possible explanation to account for the cross-regulation of the $\beta_{1}$-ARs and the $\beta_{3}$-ARs in our study is that $\beta_{1}$-ABs, by their chronic $\beta_{1}$-AR agonistic action following immunization, could desensitize $\beta_{1}$-ARs and could upregulate $\beta_{3}$-ARs as a compensatory mechanism. Some studies have described the loss of $\beta_{1}$-ARs in response to $\beta_{1}$-AABs [33] or the existence of cross-regulation between $\beta_{1}$-ARs and $\beta_{3}$-ARs in the heart when $\beta_{1}$-ARs are chronically stimulated [34]. The upregulation of $\beta_{3}$-ARs is considered useful in the first stage of the heart failure because of its protective effect by antagonizing the $\beta_{1}$-AR overstimulation.

Similarly to $\beta_{1}$-AR-immunized rats, ex vivo study has revealed the development of both diastolic and systolic dysfunctions in $\beta_{3}$ AR-immunized rats, which were characterized by a decrease of isoproterenol-induced inotropy and lusitropy. Thereby, we showed in this study that the production of cardio-stimulatory $\beta_{1}$-ABs or cardio-inhibitory $\beta_{3}$-ABs by immunizing rats with $\beta_{1}$-AR or $\beta_{3}$-AR peptide had a similar outcome on heart function. In rats immunized with $\beta_{3}$-AR peptide, the immunofluorescence assay and RT-qPCR have highlighted an upregulation of $\beta_{3}$-AR expression and mRNA in the left ventricle. Thus, it is not unreasonable to postulate that isoproterenol-mediated negative inotropic effect via $\beta_{3}$-AR activation could have contributed to the impairment of cardiac function in $\beta_{3}$-AR-immunized rats. Ideally the effet of isoproterenol in the presence of $\beta_{3}$-AR antagonist should have been performed to accurately confirm the role of the $\beta_{3}$-ARs in the impairment of isoproterenol-induced inotropy. In our study, since eNOS has been shown to play a role in the $\beta_{3}$-ARs-mediated negative inotropy [15], we tested the hypothesis that its increased expression through a larger production of NO could explain the depressed contractility observed in $\beta_{3}$-AR-immunized rats. Nevertheless, the lack of change of eNOS mRNA in these rats argues against a role of the $G_{i}$ protein/NO pathway to account for the reduced response to isoproterenol and supports the view of the existence of alternative mechanisms (i.e., reduced cAMP level via $\mathrm{G}_{\mathrm{i}}$ proteins) that need further investigation.

Although the present study has not specifically addressed the potential mechanism involved in the upregulation of ventricular $\beta_{3}$-ARs, sustained activation of $\beta_{3}$-ARs by $\beta_{3}$-ABs following long-term immunization could be considered as one possible explanation of this pattern of regulation. In accordance with this contention, recent studies have shown that stimulation of the $\beta_{3}$-ARs induced an increase of the $\beta_{3}$-AR expression [35,36]. In addition, it was shown that an upregulation of $\beta_{3}$-ARs was able to alter contractile response to isoproterenol in mice [37] and in human failing myocardium [16]. Nevertheless, those findings do not agree with the previous report $[29,38]$ showing the protective role of $\beta_{3}$-AABs against cardiac dysfunction, and do not support the point of view that $\beta_{3}$-AR upregulation may be regarded as cardioprotective mechanism that may be developed to prevent cardiomyocyte damage.

More interestingly, the dysfunctions observed ex vivo in rats immunized against the $\beta_{3}$-AR were not detected by our echocardiographic measurements. We showed that 6 months of immunization with $\beta_{3}$-AR peptide did not modify the fractional shortening and ejection fraction. The lack of correlation between ex vivo and echocardiographic parameters has already been reported [39]. In our study, the reason of this discrepancy is not clear, but it may be explained by the intervention of compensatory neurohormonal mechanisms that might operate in vivo through $\beta_{1}$-ARs to maintain myocardial contractility. This emphasizes the need to take into account the physiological context in the interpreting and the evaluation of left ventricular function. Moreover, based on our results, we cannot rule out the hypothesis that under in vivo conditions, circulating $\beta_{3}-\mathrm{ABs}$ could have exhibited a $\beta_{3}-$ antagonistic property in response to endogenous catecholamines that might be responsible for undetectable cardiac dysfunction implying $\beta_{3}$-AR component. However, whether prolonged immunization period with $\beta_{3}$-AR peptide could induce impairment of echocardiographic contractile parameters remains to be determined.

There are some limitations of this study. First, concerning the functional study of $\beta_{3}-A B s$, despite that rabbit cardiomyocytes constitute a relevant approach to assess in vitro effects of $\beta_{3}-$ $\mathrm{ABs}$, translation to in vivo or to the clinical setting should only made with caution. The $\beta_{3}$-ABs produced by immunization in rats could have a different action than that of $\beta_{3}$-AABs from patients with DCM which needs further investigation in the future. Second, concerning the influence of immunization, the immunization time of 6 months has been selected because Zuo et al. [9] have reported that the left ventricular dilation appeared from 5 months of immunization with $\beta_{1}$-AR peptide. However, in view of our results, it seems that the putative effect of $\beta_{3}-A B s$ on cardiac function is a more slowly process and hence, the immunization time would need to be increased in the future. Third, in contrast to the ex vivo experiments, our echocardiographic approach failed to find any evidence of cardiac dysfunction in $\beta_{3}$-AR-immunized rats. This suggests that measurements of fractional shortening and ejection fraction would not be always suitable for the evaluating of heart contractility under basal in vivo conditions. Therefore, future experiments using exogenous inotropic agents (i.e., isoproterenol) will be requireed to accurately quantify the change in the myocardial contractility that may occur in immunized rats. 


\section{Conclusions}

The results of the present study showed for the first time that $\beta_{3}$-ABs induced a $\beta_{3}$-AR partial agonist-like activity involving a role of $G_{i}$ proteins in isolated rabbit cardiomyocytes. In addition, we show that immunizations for 6 months producing functional $\beta_{1}$-ABs or $\beta_{3}-A B s$ led to the development of systolic and diastolic dysfunctions in heart by remodeling the $\beta_{1}-A R / \beta_{3}$-AR ratio in the left ventricle.

\section{Conflicts of interest}

None.

\section{Acknowledgements}

The authors would like to thank Chantal Thorin for her help concerning the statistical analysis and Mireille Ledevin and Sonia Becavin for the technical assistance.

\section{References}

[1] G. Wallukat, I. Schimke, Agonistic autoantibodies directed against G-protein-coupled receptors and their relationship to cardiovascular diseases, Semin. Immunopathol. 36 (2014) 351-363.

[2] B. Bornholz, S. Weidtkamp-Peters, S. Schmitmeier, C.A.M. Seidel, L.R. Herda, S.B. Felix, H. Lemoine, J. Hescheler, F. Nguemo, C. Schäfer, M.O. Christensen, C. Mielke, F. Boege, Impact of human autoantiblodies on $\beta_{1}$-adrenergic receptor conformation, activity, and internalization, Cardiovasc. Res. 97 (2013) $472-480$.

[3] J.M. Lappé, C.M. Pelfrey, W.W.H. Tang, Recent insights into the role of autoimmunity in idiopathic dilated cardiomyopathy, J. Card. Fail. 14 (2008) $521-530$

[4] R. Mobini, M. Fu, G. Wallukat, Y. Magnusson, A. Hjalmarson, J.A. Hoebeke, monoclonal antibody directed against an autoimmune epitope on the human beta1-adrenergic receptor recognized in idiopathic dilated cardiomyopathy, Hybridoma 19 (2000) 35-42.

[5] G. Wallukat, A. Kayser, A. Wollenberger, The $\beta_{1}$-adrenoceptor as antigen: functional aspects, Eur. Heart J. 16 (1995) 85-88

[6] A. Staudt, R. Mobini, M. Fu, Y. Grosse, V. Stangl, A. Thiele, G. Baumann, S.B. Felix, Beta(1)-adrenoceptor antibodies induce positive inotropic response in isolated cardiomyocytes, Eur. J. Pharmacol. 423 (2001) 115-119.

[7] Y. Magnusson, G. Wallukat, F. Waagstein, F. Hjalmarson, J. Hoebeke, Autoimmunity in idiopathic dilated cardiomyopathy: characterization of antibodies agaisnt the beta1-adrenoceptor with positive chronotropic effect, Circulation 89 (1994) 2760-2767

[8] M.A. Abdelkrim, M.Y. Mallem, G. Chatagnon, M. Gogny, J.C. Desfontis, J. Noireaud, Autoantibodies against $\beta(1)$-adrenoceptor do not affect the low-affinity state $\beta(1)$-adrenoceptor-mediated inotropy in rat cardiomyocytes, Can. J. Physiol. Pharmacol. 90 (2012) 308-316.

[9] L. Zuo, H. Bao, J. Tian, X. Wang, S. Zhang, Z. He, L. Yan, R. Zhao, X.L. Ma, H. Liu, Long-term active immunization with a synthetic peptide corresponding to the second extracellular loop of beta1-adrenoceptor induces both morphological and functional cardiomyopathic changes in rats, Int. J. Cardiol. 149 (2001) 89-94.

[10] R. Jahns, V. Boivin, L. Hein, S. Triebel, C.E. Angermann, G. Ertl, M.J. Lohse, Direct evidence for a $\beta_{1}$-adrenergic receptor-directed autoimmune attack as a cause of idiopathic dilated cardiomyopathy, J. Clin. Invest. 113 (2004) 1419-1429.

[11] W.V. Dörffel, G. Wallukat, G. Baumann, S.B. Felix, Immunoabsorption in dilated cardiomyopathy, Ther. Apher. 4 (2000) 235-238.

[12] S.B. Felix, A. Staudt, W.V. Dörffel, V. Stangl, K. Merkel, M. Pohl, W.D. Döcke, S Morgera, H.H. Neumaver, K.D. Wernecke, G. Wallukat, K. Stangl, G. Baumann, Hemodynamic effects of immunoabsorption and subsequent immunoglubulin substitution in dilated cardiomyopathy: three months results from a randomized study, J. Am. Coll. Cardiol. 35 (2000) 1590-1598.

[13] M.X. Li, X.L. Wang, J.N. Tang, X.J. Liu, J. Tian, L. Yan, H.R. Liu, Distribution and property of anti-beta3-adrenoceptor autoantibody in patients with heart failure, Zhonghua Xin Xue Guan Bing Za Zhi 33 (2005) 1114-1118.

[14] E. Montaudon, M.A. Abdelkrim, J.C. Desfonstis, Y. Mallem, Cardiovascular effects of beta1 and beta3-adrenergic receptor autoantibodies in Lewis rat, Ann. Cardiol. Angeiol. 63 (2014) 128-134.

[15] C. Gauthier, V. Leblais, L. Kobzik, J.N. Trochu, N. Khandoudi, A. Bril, J.L. Balligand, H. Le Marec, The negative inotropic effect of beta3-adrenoceptor stimulation is mediated by a nitric oxide synthase pathway in human ventricle, J. Clin. Invest. 102 (1998) 1377-1384.
[16] S. Moniotte, L. Kobzik, O. Feron, J.N. Trochu, C. Gauthier, J.L. Balligand, Upregulation of beta(3)-adrenoceptors and altered contractile response to inotropic amines in human failing myocardium, Circulation 103 (2001) 1649-1655.

[17] Q. Zhao, F. Zeng, J.B. Liu, Y. He, B. Li, Z.F. Jiang, T.G. Wu, L.X. Wang, Upregulation of $\beta_{3}$-adrenergic receptor expression in the atrium of rats with chronic heart failure, J. Cardiovasc. Pharmacol. Ther. 18 (2013) 133-137.

[18] U. Mackiewicz, E. Klemenska, A. Beresewicz, Beta-adrenergic receptors in normal and failing heart, Kardiol. Pol. 65 (2007) 294-302.

[19] T.A. Kohout, H. Takaoka, P.H. McDonald, S.J. Perry, L. Mao, R.J. Lefkowitz, H.A. Rockman, Augmentation of cardiac contractility mediated by the human beta(3)-adrenergic receptor overexpressed in the hearts of transgenic mice, Circulation 104 (2001) 2485-2491.

[20] C. Gauthier, G. Tavernier, F. Charpentier, D. Langin, H. Le Marec, Functional beta3-adrenoceptor in the human heart, J. Clin. Invest. 98 (1996) 556-562.

[21] L. Audigane, B.G. Kerfant, A. El Harchi, I. Lorenzen-Schmidt, G. Toumaniantz, A. Cantereau, D. Potreau, F. Charpentier, J. Noireaud, C. Gauthier, Rabbit, a relevant model for the study of cardiac beta 3-adrenoceptors, Exp. Physiol. 94 (2009) 400-411.

[22] Z. Anna, S. Angela, B. Barbara, R. Jana, B. Tamara, V. Csilla, D. Victor, M. Oleksiy, T. Narcisa, Heart-protective effect of n-3 PUFA demonstrated in a rat model of diabetic cardiomyopathy, Mol. Cell. Biochem. 389 (1-2) (2014) 219-227.

[23] S. Treskatsch, A. Feldheiser, A.T. Rosin, M. Sifringer, H. Habazettl, S.A. Mousa, M. Shakibaei, M. Schäfer, C.D. Spies, A modified approach to induce predictable congestive heart failure by volume overload in rats, PLoS One 9 (2014) e87531.

[24] Y. Hatakeyama, Y. Sakata, S. Takakura, T. Manda, S. Mutoh, Acute and chronic effects of FR-149175, a beta 3-adrenergic receptor agonist, on energy expenditure in Zucker fatty rats, Am. J. Physiol. Regul. Integr. Comp. Physiol. 287 (2004) R336-R341.

[25] K. Takemori, E. Yamamoto, H. Ito, T. Kometani, Prophylactic effects of elastin peptide derived from the bulbus arteriosus of fish on vascular dysfunction in spontaneously hypertensive rats, Life Sci. 120 (2015) 48-53.

[26] Y. Rautureau, G. Toumaniantz, S. Serpillon, P. Jourdon, J.N. Trochu, C. Gauthier Beta 3-adrenoceptor in rat aorta: molecular and biochemical characterization and signalling pathway, Br. J. Pharmacol. 137 (2002) 153-161.

[27] K.J. Livak, T.D. Schmittgen, Analysis of relative gene expression data using real-time quantitative PCR and the 2(-Delta Delta C(T)) method, Methods 25 (2001) 402-408

[28] Y. Gao, H.R. Liu, R.R. Zhao, J.M. Zhi, Autoantibody against cardiac beta1-adrenoceptor induces apoptosis in cultured neonatal rat cardiomyocytes, Acta. Biochim. Biophys. Sin. 38 (2006) 443-449.

[29] J. Wang, M. Li, X. Ma, K. Bai, L. Wang, Z. Yan, T. Lv, Z. Zhao, R. Zhao, H. Liu, Autoantibodies against the $\beta_{3}$-adrenoceptor protect from cardiac dysfunction in a rat model of pressure overload, PloS One 8 (2013) e78207.

[30] G. Miao, Z. Chen, X. Fang, M. Liu, G. Hao, H. An, Z. Zhang, L. Lu, J. Zhang, L Zhang, Relationship between the autoantibody and expression of $\beta_{3}$-adrenoceptor in lung and heart, PloS One 8 (2013) e68747.

[31] X. Hao, S. Li, H. Liu, B. Wu, Immunization with beta(1)-adrenoreceptor peptide induces cardiomyopathy-like changes in rabbit hearts, Chin. Med. J. 115 (2002) 170-174.

[32] L. Buvall, M.S. Täng, A. Isic, B. Andersson, M. Fu, Antibodies against the beta1-adrenergic receptor induce progressine development of cardiomyopathy, J. Mol. Cell. Cardiol. 42 (2007) 1001-1007.

[33] C.J. Limas, I.F. Goldenberg, C. Limas, Effect of antireceptor antibodies in dilated cardiomyoapthy on the cycling of cardiac beta receptors, Am. Heart J. 122 (1991) 108-114

[34] C. Ufer, R. Germack, Cross-regulation between beta 1- and beta 3-adrenoceptors following chronic beta-adrenergic stimulation in neonatal rat cardiomyocytes, Br. J. Pharmacol. 158 (2009) 300-313.

[35] Z. Zhang, L. Ding, Z. Jin, G. Gao, H. Li, L. Zhang, X. Lu, L. Hu, B. Lu, X. Yu, T. Hu, Nebivolol protects against myocardial infarction injury via stimulation of beta 3-adrenergic receptors and nitric oxide signaling, PloS One 9 (2014) e98179.

[36] X. Niu, L. Zhao, X. Li, Y. Xue, B. Wang, Z. Lv, J. Chen, D. Sun, Q. Zheng, $\beta 3$-adrenoreceptor stimulation protects against myocardial infarction injury via eNOS and nNOS activation, PloS One 9 (2014) e98713.

[37] G. Tavernier, G. Toumaniantz, M. Erfanian, M.F. Heymann, K. Laurent, D. Langin, C. Gauthier, Beta3-adrenergic stimulation produces a decrease of cardiac contractility ex vivo in mice overexpressing the human beta3-adrenergic receptor, Cardiovasc. Res. 59 (2003) 288-296.

[38] J. Wang, X. Ma, Y. Zhang, H. Wang, J. Yang, J. Dong, J. Wang, Y. Yang, B. Li, Cardiac protective effect of the autoantibody against $\beta 3$-adrenoceptor in rats with experimental heart failure, Zhonghua Xin Xue Guan Bing Za Zhi 42 (2014) 424-427.

[39] N.A. Franken, J.A. Camps, F.J. van Ravels, A. van der Laarse, E.K. Pauwels, J. Wondergem, Comparison of in vivo cardiac function with ex vivo cardiac performance of the rat heart after thoracic irradiation, Br. J. Radiol. 70 (1997) 1004-1009. 